\title{
Pemberdayaan dan Peningkatan Kapasitas Kelompok Masyarakat Lintas Komunitas Seni Kelurahan Kebun Keling Kota Bengkulu Melalui Digital Innovative Product dan Smart Management
}

\author{
Mochammad Yusa $^{1 *}$, Arie Vatresia ${ }^{1}$, Chairil Afandy ${ }^{3}$ \\ ${ }^{1}$ Informatika, Fakultas Teknik, Universitas Bengkulu, Jl. WR. Supratman, Kandang Limun, Kec. Muara Bangka Hulu, \\ Sumatera, Bengkulu 38371 \\ ${ }^{2}$ Manajemen, Fakultas Ekonomi dan Bisnis, Universitas Bengkulu, Jl. WR. Supratman, Kandang Limun, Kec. Muara \\ Bangka Hulu, Sumatera, Bengkulu 38371
}

*Email koresponden: mochammad.yusa@unib.ac.id

\author{
ARTICLE INFO \\ Article history \\ Received: 22 Agt 2020 \\ Accepted: 25 Mar 2021 \\ Published: 23 Apr 2021

\section{Kata kunci: \\ Digital Innovative \\ Product \\ E-Marketplace \\ Smart Management} \\ Lintas Komunitas Seni
}

\begin{abstract}
A B S T R A K
Background: Kelurahan Kebun Keling merupakan wilayah Kelurahan yang berbatasan langsung dengan pesisir yang merupakan salah satu destinasi wisata andalan Kota Bengkulu. Di Kelurahan tersebut terdapat kelompok masyarakat yang memilki komitmen yang kuat untuk menjadi masyarakat yang produktif secara ekonomi. Kelompok masyarakat tersebut adalah Lintas Komunitas Seni yang berdomisili di Kelurahan Kebun Keling Kecamatan Teluk Segara Kota Bengkulu. Seni yang digeluti pada komunitas ini adalah seni musik, seni motor klasik, seni rupa dan seni murat (street art). Mitra ini mengalami beberapa hambatan dalam menghadapi era digitalisasi industri kreatif diantaranya adalah tingkat pemahaman tentang teknologi disain digital, manajemen organisasi dan produksi. Tujuan dilakukannya kegiatan ini adalah menerapkan ipteks melalui Digital Innovative Product dan Smart Management yang menjadi inisiasi kemadirian ekonomi kelompok masyarakat di Kelurahan Kebun Keling Kecamatan Teluk Segara. Metode: Metode pelaksanaan kegiatan ini dibagi menjadi 3 (tiga) kegiatan pokok yaitu: (1) Implementasi teknik digital drawing dengan konversi gambar kertas menjadi node/curva/bitmap menggunakan software disain grafis, (2) pembuatan dan pendampingan pembuatan handycraft yang berasal dari seni digital konversi untuk menjadi produk yang siap jual menggunakan teknik sablon afdruk, (3) pendampingan dan pelatihan manajemen keuangan dengan metode harga pokok produksi untuk menentukan nilai jual, laba dan rugi, serta manajemen aset. Target kegiatan ini diharapkan dapat meningkatkan kemampuan teknologi dan manajemen mitra Lintas Komunitas Seni, peningkatan kemampuan, dan peningkatan pengetahuan mitra. Hasil: Hasil dari kegiatan ini disimpulkan bahwa tingkat pengetahuan mitra meningkat dengan rata-rata 4,20 yang berarti dalam range baik. Kesimpulan: Perlu adanya media lain di luar kegiatan yang dapat dimanfaatkan untuk pengembangan lebih lanjut.
\end{abstract}

\section{A B S T R A C T}

Background: Kebun Keling Sub-district is an area of coast in Bengkulu. It is one of Bengkulu City's mainstay tourist destinations. In this sub-district, there is a community group which has a strong commitment to become productive people. The art community group is the Lintas Komunitas Seni which is based on Kebun Keling Subdistrict in Teluk Segara District, Bengkulu City. This community incorporates to musical art, classical motobike art, mural art, and fine art. This community experienced several obstacles in facing the digitalization era of the creative industry, including the level of understanding of digital design technology, organizational management and production. The aim of this community service activity is to apply science and technology through Digital Innovative Products and Smart Management. It is the initiation of economic independence for member of this art community group in Kebun Keling sub-district, Teluk Segara District. Method: The method of implementing this 
activity is divided into 3 (three) main activities, such as: (1) Implementing digital drawing techniques by converting paper images into nodes / curves / bitmaps using graphic design softwares, (2) making and assisting in producing handicrafts from digital art conversion to become a ready-to-sell product using afdruk screen printing techniques, (3) accompanying financial management assistance and training with the cost of production method to determine the selling value, profit and loss, and asset management. The activity target is to improve the technology and management capabilities, soft and hard skills, and knowledge of the partner. The result we obtained from this community services is that improving the knowledge skill of the partner is increasing with average of 4,20 . Conclusion: There needs to be other media outside of activities that can be used for further development.

() 2021 by authors. Lisensi Jurnal Solma, UHAMKA, Jakarta. Artikel ini bersifat open access yang didistribusikan di bawah syarat dan ketentuan Creative Commons Attribution (CC-BY) license.

\section{PENDAHULUAN}

Kelurahan Kebun Keling merupakan salah satu kelurahan yang berada di kecamatan Teluk Segara. Kelurahan kebun keling merupakan kelurahan terkecil kedua dalam kecamatan teluk segara dengan luas wilayah sebesar 16 Ha (Gambar 1). Letak geografis Kelurahan kebun Keling adalah sebelah utara berbatasan langsung dengan Pantai Tapak Paderi, sebelah timur Kelurahan Pasar berkas, sebelah barat dengan kelurahan Malabero, dan selatan dengan Kelurahan Pasar Jitra. Penduduk kelurahan Kebun Keling terdiri dari 595 penduduk berjenis kelamin laki-laki dan 554 penduduk berjenis kelamin perempuan berbatasan langsung dengan pesisir pantai dan Benteng Malborough, Keluruhan Kebun Keling menjadi salah satu destinasi wisata yang paling sering dikunjungi baik wisatawan domestik maupun mancanegara (BPS, 2018).

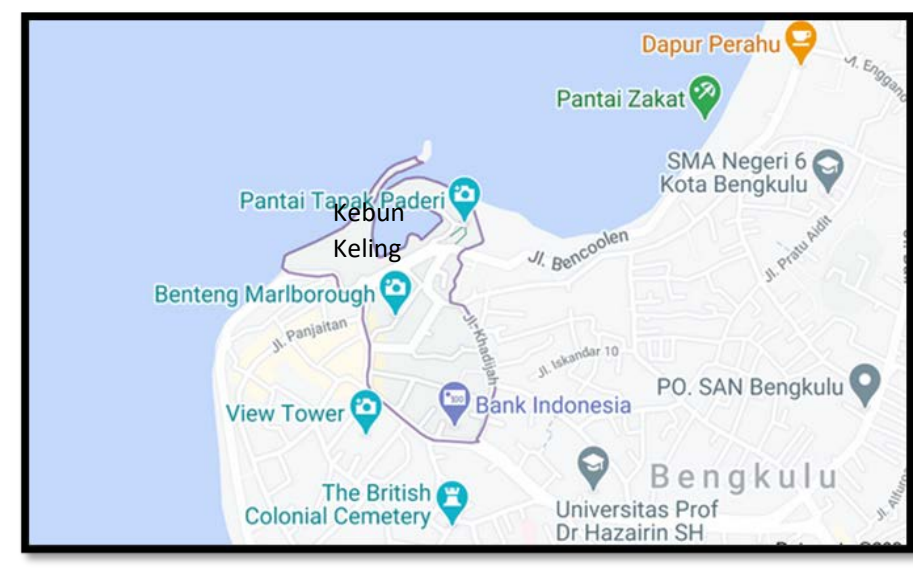

Gambar 1. Peta Wilayah Kelurahan di Kecamatan Teluk Segara

Berada di kawasan pesisir yang merupakan destinasi wisata, wilayah strategis Kelurahan Kebun tidak menjamin peningkatan ekonomi masyarakat untuk meningkat. Hal ini dibuktikan dengan data bahwa mayoritas penduduk di Kelurahan Kebun Keling masih berprofesi sebagai pedagang rumahan atau kelontong, Penjaga Parkir, ataupun pedagang yang berjualan di Kelurahan Pasar Baru. Rata-rata pendapatan penduduk juga masih sangat minim. Padahal potensi pariwisata yang ada di Kelurahan tersebut dapat dimaksimalkan melalui pemberdayaan masyarakat. 


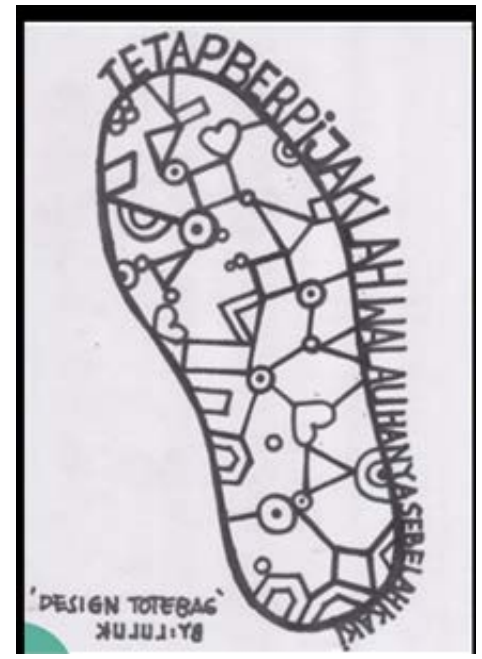

Gambar 2. Contoh Seni rupa Komunitas Lintas Seni

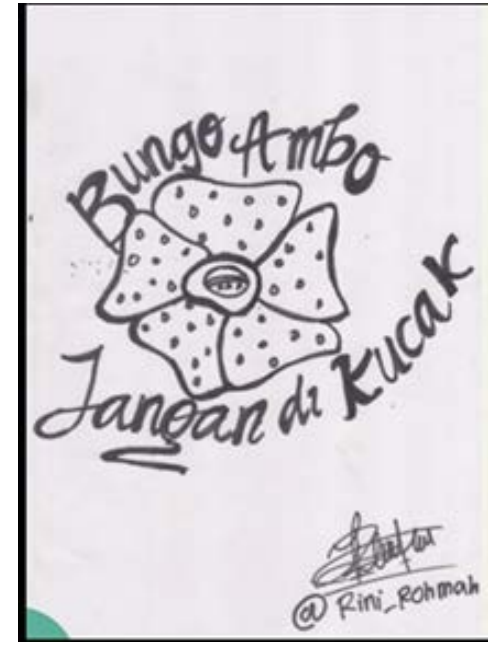

Gambar 3. Contoh seni rupa raflesia

Lintas Komunitas Seni merupakan komunitas yang berdomisili di Kelurahan Kebun Keling. Komunitas ini merupakan gabungan dari komunitas-komunitas kecil seperti atlit mural, seniman seni rupa, musisi, dan motor klasik. Jumlah total anggota yang tercatat aktif saat ini adalah sekitar 30 orang. Komunitas ini lebi cenderung bergerak di bidang seni dan budaya. Seni dan budaya yang dikembangkan dalam kelompok masyarakat ini adalah seni rupa dan seni mural (industri kreatif) yang dipelajari secara otodidak. Di Eropa industri kreatif lebih dikenal dengan nama ekonomi kreatif (Howkins, 2013) atau industri budaya (Hesmondhalgh, 2007) yang berarti indsutri yang industri yang berasal dari pemanfaatan kreativitas, keterampilan serta bakat individu untuk menciptakan kesejahteraan serta lapangan pekerjaan dengan menghasilkan dan mengeksploitasi daya kreasi dan daya cipta individu tersebut (Anonim, 2019). Komunitas ini juga aktif di berbagai pameran seni lokal. Karya seni yang dihasilkan berupa seni rupa (Gambar 2 dan 3) yang biasanya dijual di pameran. Namun pendapatan dari penjualan ini masih sangat minim. Sub bagian dari komunitas ini adalah atlit mural, yaitu kumpulan pencinta seni jalanan (street art) yang biasanya membuat gambar pada dinding-dinding yang kurang terawat untuk kebutuhan kampanye dan penyuluhan (Gambar 4). Pedapatan dari komunitas ini masih sangat minim yaitu berasal dari proyek-proyek perusahan dan pemerintah untuk membuat iklan pelayanan masyarakat menggunakan media-media seperti dinding. Proyek tersebut tidak selalu muncul secara kontinyu sehingga seni tersebut hanya dijadikan hobi oleh anggota komunitas dan anggota komunitas memilih pekerjaan lain seperti penjaga parkir, musisi cafe, buruh kasar, pekerja paruh waktu dan lain-lain. Padahal potensi seni yang dibuat oleh seniman tersebut memilki potensi untuk menjadi produk inovasi yang mempunyai nilai jual.

Berdasarkan hasil observasi awal yang dilakukan, Lintas Komunitas Seni yang diprakarsai oleh Ibu Yurika Pratiwi ini memiliki kemauan yang kuat untuk mengembangkan karya seni yang diciptakan oleh anggota komunitas. Berdasarkan hasil wawancara calon pelaksana, anggotaanggota yang tergabung dalam komunitas ini masih belum paham bagaimana seni ini dapat survive dan peluang industri kreatif apa yang dapat dikembangkan di jaman sekarang ini. 


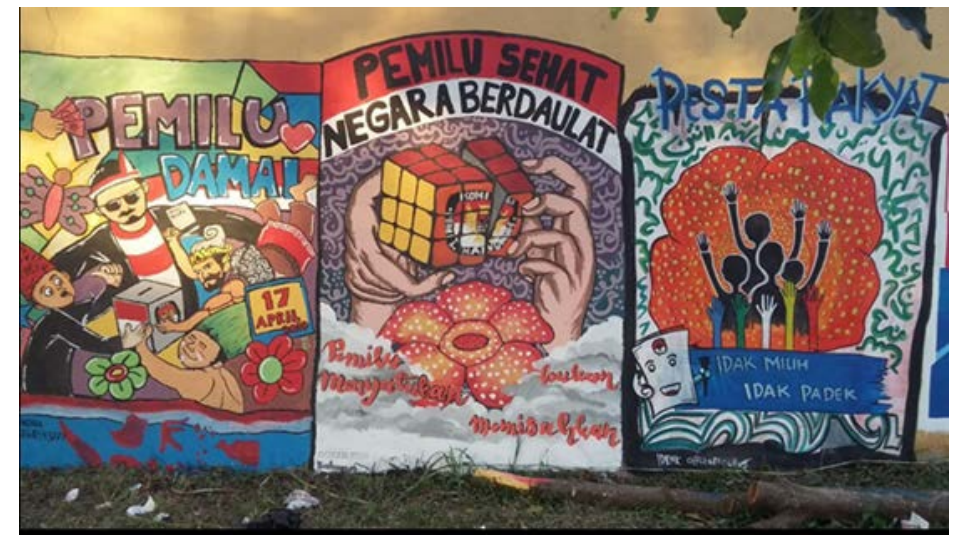

Gambar 4. Seni Mural Bengkulu

Ketidakmampuan mengikuti perkembangan teknologi dan kemampuan managemen menjadi hal utama yang menjadi penghalang untuk mengembangkan kreativitas yang dimiliki oleh anggota komunitas tersebut demi tercapainya misi Pemerintahan Kota Bengkulu untuk meningkatkan sumberdaya industri kreatif untuk menunjang kepariwisataan menuju Wonderful Bengkulu Tahun 2020.

\section{MASALAH}

Berdasarkan hasil konservasi awal calon pelaksana terhadap mitra, terdapat beberapa prioritas masalah yang dihadapi oleh calon mitra yang akan menjadi tujuan dari kegiatan ini ditinjau dari berbagai aspek seperti SDM, Manajemen, Produk, Pemasaran, dan Fasilitas. Rincian Permasalahan dapat dilihat pada Tabel 1.

Tabel 1. Aspek dan permasalahan mitra

\begin{tabular}{ll}
\hline \multicolumn{1}{c}{ Aspek } & \multicolumn{1}{c}{ Permasalahan Mitra } \\
\hline SDM & - Keterampilan masih terbatas, masih sebatas seni yang konvensional. \\
& - Kemampuan pemahaman teknik disain digital menggunakan teknologi \\
& komputer masih terbatas khususnya teknologi disain. \\
& - Belum memahami kemampuan pemindahan gambar konvensional ke bentuk \\
& curve atau bitmap sehingga dapat dijadikan produk inovasi yang dapat \\
& dipasarkan. \\
Manajemen & - Manajemen produksi masih belum baik karena belum adanya kompetensi \\
& keahlian khusus dalam memanejemen proses produksi sampai dengan \\
& penjualan produk. \\
Produk & Produk masih terbatas, hanya sebatas lukisan konvensional dan seni jalanan \\
& (mural) \\
& - Tidak ada produk lain yang dihasilkan berupa produk ekonomi kreatif hasil \\
Pemasaran & dari kreasi digital. \\
& Pemasaran produk karya seni masih sebatas mulut ke mulut dan proyek dari \\
& instansi baik pemerintah maupun swasta untuk seni mural \\
Fasilitas & Pemasaran seni rupa masih dicangkupan pameran seni. \\
& Mayoritas anggota kelompok komunitas masih belum memilki alat untuk \\
& menciptakan produk hasil karya seni yang berbentuk karya lain yang memilki \\
& nilai jual
\end{tabular}


Berdasarkan prioritas masalah tersebut, maka sasaran kegiatan yang akan dilaksanakan sesuai dengan hasil kesepepakatan bersama calon mitra dirincikan sesuai aspek permasalahan pada Tabel 2 berikut ini.

Tabel 2. Sasaran kegiatan yang disepakati

\begin{tabular}{|c|c|}
\hline Aspek & Sasaran kegiatan yang disepakati \\
\hline SDM & $\begin{array}{l}\text { Pelatihan dan pendampingan transfer disain dari konvensional menjadi digital } \\
\text { yang memiliki nilai inovasi produk yang tinggi dan dapat diimplementasi menjadi } \\
\text { produk-produk seni yang dapat diedarkan di pasaran melalui teknik digital } \\
\text { converting menggunakan multimedia software untuk meningkatkan keahlian. }\end{array}$ \\
\hline Manajemen & Pelatihan dan Pendampingan Manajemen menggunakan Harga Pokok Produksi. \\
\hline Produk & $\begin{array}{l}\text { Pembinaan produksi karya industri kreatif yang menghasilkan produk seperti } \\
\text { kaos dan Goodiebag dengan ciri khas Bengkulu dengan menciptakan produk yang } \\
\text { layak jual. } \\
\text { Pendampingan dan pelatihan pembuatan souvenir dengan inovasi karya seni } \\
\text { digital dari masing-masing anggota yang memiliki identitas bengkulu dan dapat } \\
\text { dipasarkan minimal di pasar wisatawan yang mengunjungi provinsi Bengkulu. }\end{array}$ \\
\hline
\end{tabular}

\section{METODE PELAKSANAAN}

Metode pelaksanaan ini dilakukan sesuai dengan prioritas masalah yang sudah disepakati oleh pelaksana dan mitra. Metode pelaksanaan adalah metode yang dilakukan untuk memecahkan masalah yang dihadapi mitra. Dalam pelaksanaan kegiatan ini dibagi menjadi 3 (tiga) kegiatan pokok yaitu: (1) Implementasi teknik digital drawing dengan konversi gambar kertas menjadi node/curva menggunakan software disain grafis, (2) pembuatan dan pendampingan pembuatan handycraft yang berasal dari seni digital konversi untuk menjadi produk yang siap jual menggunakan teknik sablon afdruk, dan (3) pendampingan dan pelatihan manajemen keuangan dengan metode harga pokok produksi untuk menentukan nilai jual, laba dan rugi, serta manajemen aset.

\section{Implementasi teknik digital drawing dengan konversi gambar kertas menjadi node/curva/bitmap menggunakan software disain grafis}

Dalam era saat ini, disain grafis merupakan salah satu kemampun pendukung yang dapat memiliki peran penting dalam pembedayaan ekonomi kreatif (Azhari et al., 2020) dan memberika peprspektif inovasi yang baru (promosi) untuk menghadapi era globalisasi (Astuti \& Hartiyah, 2016; Yahya et al., 2020). Teknik digital drawing menggunakan software komputerisasi yang dilakukan untuk meningkatkan kemampuan pemahaman anggota lintas komunitas seni dalam pemahaman teknologi komputer khususnya disain grafis yang merujuk pada referensi (Komputer, 2007) dan (Enterprise, 2018) Kegiatan pelaksanaan ini terdiri dari beberapa tahap yaitu:

1. Pembuatan konsep seni rupa yang akan dikonversi menggunakan media kertas. Pada tahap ini mitra berpartisipasi untuk membuat suatu karya gambar seni.

2. Pelatihan dengan metode ceramah tentang pengenalan perangkat lunak disain grafis corel draw. Kemudian dilanjutkan dengan pelatihan yang disertai praktik pengkonversian disain konvensional menjadi disain digital dalam bentuk node/curve/bitmap menggunakan software 
Corel Draw. Mitra berpartisipasi dalam menyiapkan tempat pelatihan dan komputer jinjing pribadi/sewa bagi yang tidak memilki komputer jinjing.

3. Evaluasi tingkat pemahanan mitra secara kognitif dan psikomotor melalui sebaran kuesioner terkait dengan pemahan masing-masing individu.

4. Tindak lanjut hasil evaluasi.

\section{Pembuatan dan pendampingan pembuatan handycraft yang berasal dari seni digital konversi} untuk menjadi produk yang siap jual menggunakn teknik sablon afdruk

Kegitan ini dilaksanakan untuk mengatasi aspek produk yang dialami oleh mitra. Target dari kegiatan ini adalah mitra dapat memahami instalasi alat sablon dengan teknik afdruk dan dapat mengimplementasikan menjadi produk layak jual. Teknik Sablon juga merupakan salah satu strategi yang dapat meningkatkan ekonomi masyarakat (Suhendri, 2015; Mulyawati \& Pradita, 2018). Adapun kegiatan sejenis yang sudah dilaksanakan dan memiliki manfaat adalah seperti yang dilakukan oleh Saifudin \& Nurhalimah (2019) dan Hidayat et al., (2020). Dalam paper tersebut disebutkan bahwa pembuatan produk yang dirancang berdasarkan digital disain memiliki efek yang signifikan dalam membantu pengembangan skil masyarakat. Sehingga pada kegiatan ini penerapan metode penyablonan untuk pembuatan produk akan diadaptasi. Kegiatan pelaksanaan ini terdiri dari beberapa tahap yaitu:

1. Persiapan praktik sablon merupakan tahap pertama dalam sub kegiatan ini. Mitra berpartisipasi dalam menyiapakan tempat/workshop/bengkel praktik dan menyiapkan. Pelaksana melakukan proses pengadaan bahan baku perancangan alata penyablonan.

2. Perancangan dan instalasi alat sablon afdruk. Pelaksana memperagakan cara penginstalan alat afdruk. Mitra berpartisipasi mengikuti tata cara penginstalan alat sablon.

3. Praktik pembuatan handycraft seperti $t$-shirt dan goodiebag. Mitra melakukan penyablonan $T$ Shirt dan Goodiebag sebagai output hasil disain pada kegiatan pertama.

4. Evaluasi. Sub kegiatan ini dilakukan untuk melihat detail karya yang dihasilkan oleh mitra. Sub kegiatan ini meliputi pengecekan hasil sablon kaos dan konsultasi terkait dengan pemahaman sampai menjadi handycraft.

5. Pendampingan dan pelatihan manajemen keuangan dengan metode harga pokok produksi untuk menentukan nilai jual, laba dan rugi, serta manajemen aset

Pembukuan sederhana dan penentuan harga pokok produksi (HPP) merupakan hal penting dalam menentukan harga sehingga organisasi dapat bersaing satu dengan lainnya (Rina Fariana et al., 2020). Dokumentasi yang tepat memungkinkan manajemen dalam usaha dapat mengetahui neraca organisasi dengan baik dan benar. Berdasarkan hal tersebut, maka dirasa penting untuk melaksanakan kegiatan pelatihan manajemen keuangan kepada mitra sebagai upaya mencapai kemandirian ekonomi yang konsisten (Nilawati et al., 2020). Kegiatan ini dilakukan berdasarkan permasalahan mitra terkait dengan manajemen organisasi dan produksi dalam hal penentuan harga pokok produksi. Kegitan meliputi:

1. Tahap persiapan, yang terdiri dari tahap penyiapan yaitu pelaksana menyipakan bahan administrasi sesuai dengan kebutuhan pelaksanaan pelatihan, melakukan koordinasi dengan para komunitas, menyiapkan materi pelatihan. Mitra berpartisipasi menyiapkan komponen pelatihan seperti laptop dan ATK setrta tempat pelatihan.

2. Pelaksanaan pelatihan untuk membuat pembukuan sederhana untuk menentukan modal dan harga jual barang hasil kerajinan sablon, simulasi terbatas membuat pembukuan 
sederhana untuk menentukan modal dan harga jual barang hasil sablon yang dihasilkan anggota Lintas Komunitas Seni di Kelurahan Kebun Keling yang telah dibuat dalam pelatihan sebelumnya.

3. tahap evaluasi, yang terdiri dari persentasi hasil pelatihan, koreksi dari pelaksana.

\section{HASIL DAN PEMBAHASAN}

Pada kegiatan yang telah dilaksanakan pada sejumlah 16 orang dari komunitas lintas seni. Dampak ekonomi dan sosial setelah dilaksanakannya kegiatan pengabdian masyarakat ini dijelaskan pada sub bab per kegiatan yang telah dilaksanakan berikut ini.

\section{Implementasi teknik digital drawing dengan konversi gambar kertas menjadi node/curva/bitmap menggunakan software disain grafis}

Kegiatan pelatihan ini dimaksudkan untuk mengetahui bagaimana mengkonversi bentuk gambar yang dimulai dari skecthing gambar manual (Gambar 5). Kemudian setelah didapatkan gambar manual, dilakukan pelatihan pengembangan kopetensi dengan metode ceramahdan praktik (gambar 6). Dalam pelatihan ini, kegiatan dimulai dengan pengenalan dengan pembuatan sketch gambar yang dilakukan peserta. Kemudian kegitan dilanjutkan dengan pengenalan software disain grafis corel draw dilanjutkan dengan praktek scanning disain menjadi digital kemudian dilakukan praktik pembuatan disain digital.

Kemudian setelah selesai peserta diperkenankan untuk mencetak disain digital di kertas yang sudah disediakan kemudian disain tersebut akan menjadi disain yang akan dicetak ke dalambentuk kaos dengan teknologi afdruk (kegiatan poin B). Dampak sosial yang didapatkan dari kegiatan ini adalah kemampuan peserta tentang pemahaman digital kreatif meningkat. Hal tersebut didapatkan dari hasil evaluasi dalam bentuk kuesioner yang dibagikan kepada peserta.

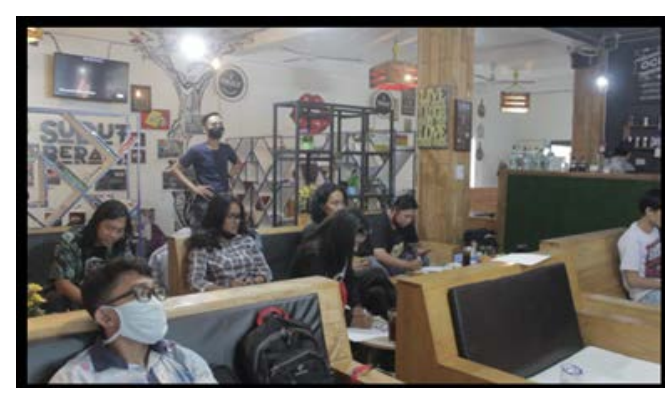

Gambar 5. Pelatihan Konversi gambar konvensional menjadi digital

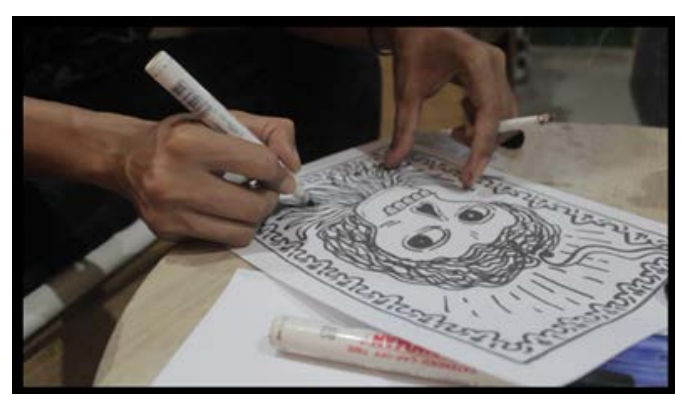

Gambar 6. Pembuatan sketch gambar manual oleh peserta

Pembuatan dan pendampingan pembuatan handycraft yang berasal dari seni digital konversi untuk menjadi produk menggunakan teknik sablon afdruk.

Setelah kegiatan rangkaian pertama selesai, kegiatan selanjutnya adalah praktik pembuatan handycraft seperti kaos dan goodiebag. Kegiatan ini dilaksanakan di workshop. Dalam kegiatan ini pelaksana telah menyediakan alat-alat sablon seperti screen sablon, alat pengering, semprot air, cairan pengental, cat baju, kaos, goodiebag dan lain-lain. Kemudian seluruh peserta yang dihadir didemokan sebanyak satu kali tentang pembuatan sablon pada kaos (Gambar 7). Setelah selesai ceramah (Gambar 8) kemudian setiap peserta melakukan praktek sablon pada kaos tersebut. 
Dalam kegiatan ini, peserta dibantu oleh tm dari truly creative sebagai partner dari mitra untuk kegiatan pelatihan dan pendampingan. Dalam kegiatan yang dilangsungkan, peserta sangat exited. Banyak diskusi yang tercipta tentang bagaimana pembuatan kaos yang efektif maupun tentang ditail-ditail pembuatan handycraft dengan metode afdruk.

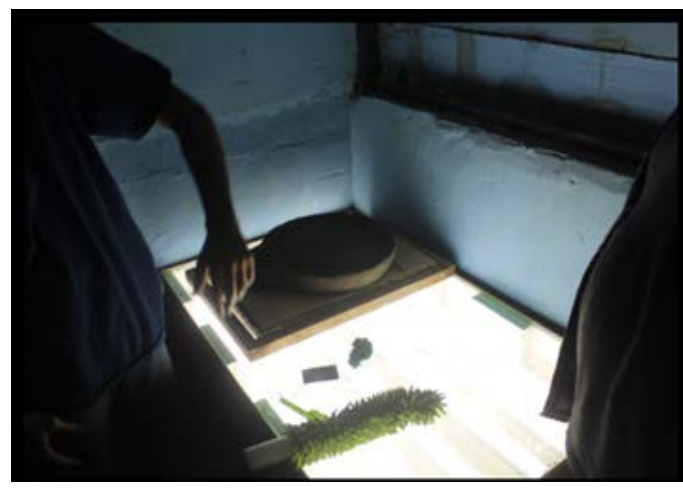

Gambar 7. Ujicoba dan praktek pembuatan karya

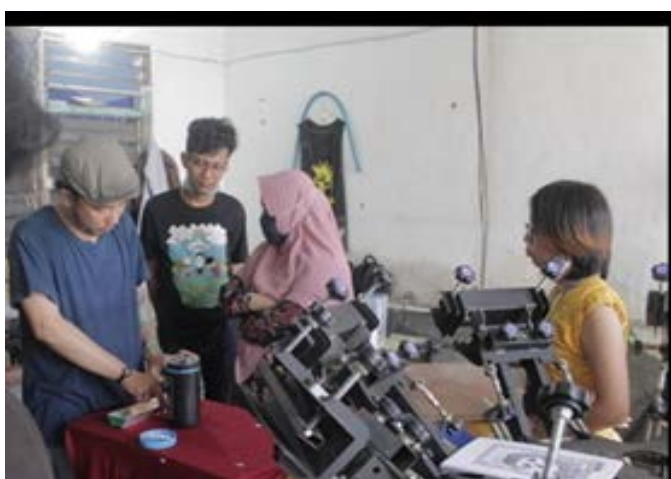

Gambar 8. Konsultasi tentang teknik penyablonan

Pendampingan dan pelatihan manajemen keuangan dengan metode harga pokok produksi untuk menentukan nilai jual, laba dan rugi, serta manajemen aset

Setelah selesai melaksanakn praktik penyablonan kegiatan selanjutnya yang dilaksanakan adalah pendampingan dan pelatihan manajemen keuangan dengan metode penetuan harga pokok produksi (Gambar 9 dan 10). Penyampaian materi tersebut dilaksanakan dengan metode ceramah. Terdapat diskusi tanya jawab terkait dengan pelatihan yang dilakukan oleh dan pelaksana pengabdian. Selain diskusi tanya jawab terdapat beberapa peserta juga yang menanyakan tertang permodalan serta branding. Selain itu, pembuuan manajemen keuangan juga dilaksanakan dalam kegiatan ini. Outcome dari kegiatan ini adalah peningkatan kapasitas manajemen peserta terkait produksi barang sehingga mendapatkan tata kelola keuangan yang sehat.

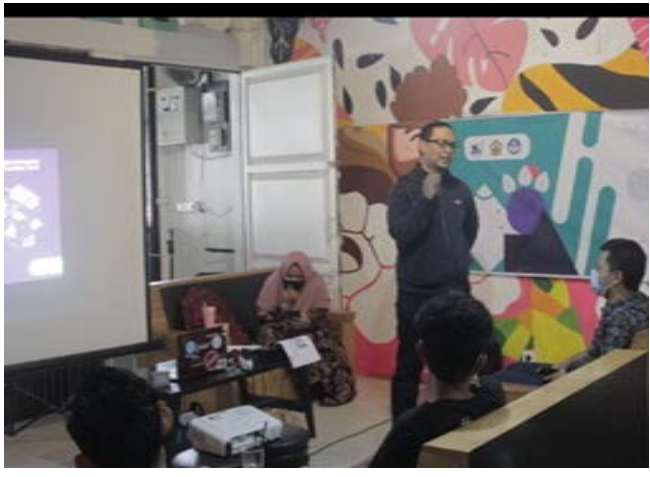

Gambar 9. Penyampaian materi tentang HPP

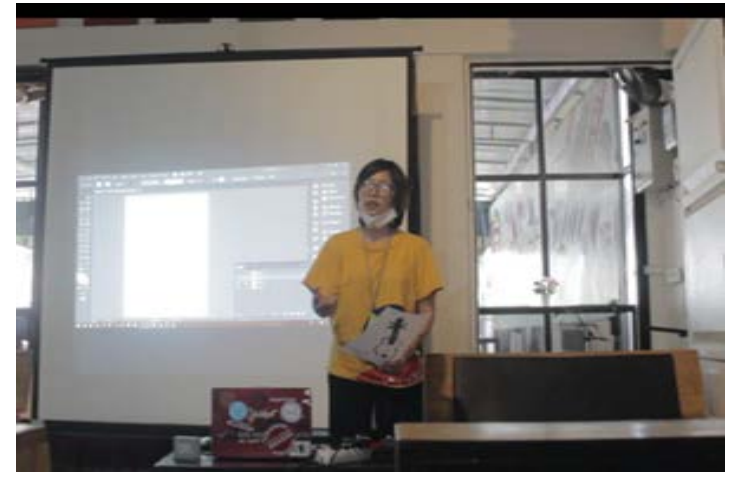

Gambar 10. Presentasi Peserta tentang pembukuan dan penentuan harga pokok produksi

Dari rangkaian kegiatan yang sudah dilaksanakan tersebut, kemudian pelaksana kegiatan melakukan evaluasi penuh dengan menyebarkan kuesioner menggunakan form online. Hal 
tersesbut digunakan sebagai bahan pertimbangan evaluasi terkait dengan tingkat kepemahaman peserta/mitra. Indicator tingkat kepemahaman mitra dilakukan menggunakan alat bantu kuesione. Terdapat beberapa pengukuran yang dilaksanakan 3 bagian pengukuran yang dilaksanakan menggunakan skala likert yaitu tingkat pemahaman, penyampaian materi, dan kesempatan berdiskusi atau Tanya jawab. Butir pertanyaan 1-6 merupakan representasi untuk tingkat pemahaman mitra, 7-9 mewakili tingkat kemampuan pemateri dalam menyampaiakan materi, dan butir pertanyaan 10 dan 11 digunakan untuk mengukur tingkat evaluasi melalui Tanya jawab (Tabel 3). Skala pengukuran yang digunakan adalah range 1 (satu) sampai dengan 5 (lima) dimana nilai skala 1 untuk sangat kurang dan poin 5 untuk sangat baik dimana poin naik secara simultan.

Tabel 3. Skala Evaluasi

\begin{tabular}{cc}
\hline Skala Range & Nilai \\
\hline Sangat Kurang & 1 \\
Kurang & 2 \\
Cukup & 3 \\
Baik & 4 \\
Sangat baik & 5 \\
\hline
\end{tabular}

Dari kuesioner yang disebarkan populasi komunitas yang tergabung dalam lintas komunitas seni dan yang hadir dalam kegiatan tersebut, sebanyak 13 peserta yang mengisi kuesioner dari total 16 orang peserta yang mengikuti kegiatan atau sebesar 81,25 persen. Dengan rincian 30,8 persen dari komunitas motor klasik, 30,8 persen dari komunitas musik, 30,8 persen dari komunitas seni rupa dan 7,7 persen dari komunitas mural. Hal ini menunjukkan bahwa secara statistik sudah mencukupi untuk mendapatkan data yang valid.

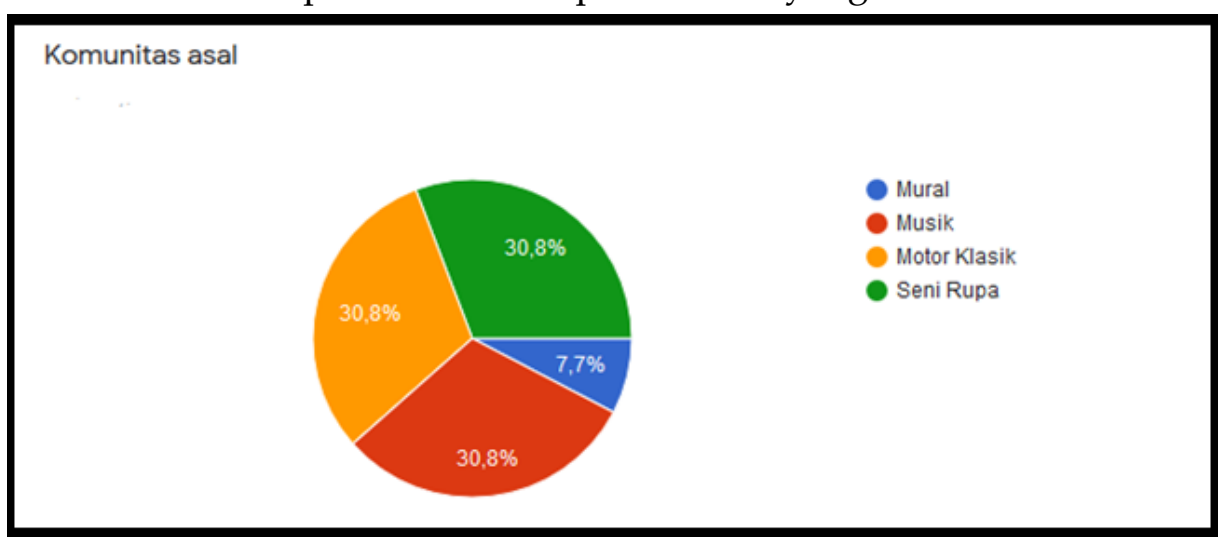

Gambar 11. Grafik populasi

Dari hasil evaluasi yang didapatkan (Tabel 4), rerata nilai secara keseluruhan dari kegiatan pengabdian ini adalah baik yaitu dengan rata-rata 4,29. Range kategori penilaian adalah 0,00 - 1,5 adalah sangat tidak baik, 1,5 - 2,5 adalah tidak baik, 2,5 - 3,6 tergolong cukup, 3,6 - 4,2 termasuk baik, dan sangat baik berada di kisaran 4,2 sampai dengan 5,0.

Tabel 4. Summary Evaluasi

\begin{tabular}{llc}
\hline & \multicolumn{1}{c}{ Pernyataan Evaluasi } & Rerata Nilai \\
\hline Pemahaman & Materi Teroganisir dan mudah dimengerti & 4,15 \\
Materi & Materi sangat relevan dan telah sesuai dengan kebutuhan saya & 4,69 \\
& untuk mengembangkan kemampuan & \\
\multicolumn{2}{l}{ Doi: https://doi.org/10.22236/solma.v10i1.5434 } & solma@uhamka.ac.id | 129
\end{tabular}


Materi sudah sangat sangat mencukupi untuk 4,62 mengembangkan kemampuan konversi data digital

Materi sudah sangat sangat mencukupi untuk memahami bagaimana memberikan harga yang pantai untuk penjualan souvenir seperti kaos dan goodiebag

Materi sudah sangat sangat mencukupi untuk mempraktikkan bagaimana membuat disain menjadi sebuah karya yang bernilai jual (kaos dan goodie bag)

dengan materi ini, akan memudahkan saya dalam mengambangkan kemampuan digital saya dalam mengembangkan ekonomi kreatif

\section{Rerata}

Penyampaian Pemateri sangat memahami materi yang disampaikan Materi Alokasi Penyampaian waktu

Pemateri menyampaikan materi dengan baik dan mudah 4,54 dimengerti

\section{Rerata}

Diskusi dan Tanya Jawab jelas

\section{Rerata}

Tabel 6 merupakan detail dari hasil evaluasi kegiatan yang sudah dilaksanakan. Dari hasil tersebut ditunjukkan bahwa untuk faktor tingkat pemahaman mitra skor rata-rata yang didapatkan adalah 4,4. Range tersebut terkategori sangat baik. Hasil tersebut menunjukkan bahwa terjadi peningkatan yang signifikan untuk pemahaman materi dari anggota mitra. Faktor yang kedua yang dievaluasi adalah pemateri. Dari evaluasi yang diisi oleh masing-masing peserta dapat dilihat bahwa tingkat penyampai materi tergolong baik. Sedangkan untk faktor yang ketiga terkait dengan kesempatan mitra untuk berdiskusi dan Tanya jawab berada dikisaran 3,79 atau tergolong baik. Faktor yang berkaitan dengan diskusi dan Tanya jawab merupakan penilaian yang paling rendah. Berdasarkan kegiatan yang sudah dilaksanakan, hal ini sudah sangat sesuai dengan kenyataan yang ada di lapangan. Dengan keterbatasan waktu dan masih dalam keadaan pandemic Covid-19 adalah kendala utama dalam memberikan waktu yang cukup untuk berdiskusi secara langsung. Berdasarkan hal tersebut, untuk tindak lanjut yang akan dilaksanakan adalah membuat sebuah ruang diskusi online dengan memanfaatkan teknologi informasi.

Secara keseluruhan, hasil evaluasi menunjukkan bahwa kegiatan yang dilaksanakan sudah baik dan hampir sangat baik (excellent). Namun daripada itu, terdapat skala yang masih ada 2 (dua) faktor yang tergolong baik yaitu dalam kisaran 3,6-4,2 yaitu faktor penyampaian materi dari instruktur dan diskusi dan Tanya jawab. Namun secara umum dapat dikatakan bahwa kegiatan yang dilakukan sudah berjalan dengan lancara dan tingkat pemahaman mitra meningkat. Namun terdapat beberapa kendala yang ditunjukkan berdasarkan hasil evaluasi terendah yaitu kesempatan berdiskusi dan tanya jawab. Hal tersebut terjadi karena pelaksaan kegiatan dilakukan 
secara luring dan dilaksanaan bersamaan dengan pandemic Covid-19. Mesikpun terdapat kendala, secara rata-rata kegiatan dapat berjalan dengan sangat baik dan lancar.

\section{KESIMPULAN}

Kegiatan yang telah dilaksanakan adalah kegiatan peningkatan kapasistas konversi digital menggunakan teknologi ICT (design softwares dan hardwares), praktik dan pendampingan pembuatan handycraft dari disain yang dibuat mitra, dan pelatihan dan pendampingan manajemen harga pokok produksi dan manajemen pemasaran. Dari hasil evaluasi yang dilaksanakan menunjukkan bahwa tingkat pemahaman peserta dalam memahami materi secara umum sudah baik yaitu pada kisaran rata-rata 4,2 dengan rentang skala 0-5. Di masa pandemi ini, alokasi waktu kegiatan dirasa masih dalam skala cukup. Sehingga butuh media lain di luar kegiatan yang dapat dimanfaatkan untuk pengembangan lebih lanjut dari mitra. Pengurangan pelatihan dan peningkatan kapasitas yang dilakukan secara tatap muka akan mengurangi kemungkinan transmisi pandemi covid-19.

\section{UCAPAN TERIMA KASIH}

Kegiatan pengabdian masyarakat ini didanai oleh Direktorat Riset dan Pengabdian Masyarakat Deputi Bidang Penguatan Riset dan Pengembangan Kementerian Riset dan Teknologi / Badan Riset dan Inovasi Nasional (KEMRISTEKBRIN) Republik Indonesia sesuai dengan Kontrak Pelaksanaan Program Pengabdian Masyarakat Nomor: 049/SP2H/PPM/DRPM/2020 tanggal 13 Maret 2020. Ucapan terima kasih juga kami sampaikan kepada KEMRISTEKBRIN dan Lembaga Penelitian dan Pengabdian Masyarkat (LPPM) Universitas Bengkulu atas dukungan yang diberikan.

\section{DAFTAR PUSTAKA}

Anonim. (2019). Ekonomi Kreatif: Pengertian, Ciri-Ciri, Jenis, dan Perkembangannya. Maxmanroe.com. https://www.maxmanroe.com/vid/bisnis/ekonomi-kreatif.html

Astuti, E. D., \& Hartiyah, S. (2016). Pelatihan Desain Grafis \& Cetak Digital di Lingkungan Pondok Pesantren. Jurnal FE Unsiq, 11(1), 36-48.

Azhari, W., Purwanto, P., Rifa'i, F., \& Pudail, M. (2020). Pemberdayaan Masyarakat Melalui Pelatihan Desain Grafis di Balai Latihan Kerja Komunitas Pesantren Pada Masa Pandemi COVID-19. LOGISTA Jurnal Ilmiah Pengabdian Kepada Masyarakat, 4(2), 487-493. https://doi.org/10.25077/logista.4.2.487493.2020

BPS. (2018). Kecamatan Teluk Segara dalam Angka. BPS.

Enterprise, J. (2018). Photoshop dan Coreldraw: Edisi Revisi dan Update. Elek Media Komputindo.

Hesmondhalgh, D. (2007). The Cultural Industries. Sage Publication.

Hidayat, M. N., Umami, Z., \& Bashori, M. H. (2020). Pelatihan Desain Produk Dan Iklan Digital Untuk Karang Taruna Kelurahan Gajahmungkur. Abdimasku: Jurnal Pengabdian Masyarakat, 3(3), 15164. https://doi.org/10.33633/ja.v3i3.110

Howkins, J. (2013). The Creative Economy: How People Make Money from Ideas. In 2nd Edition. Penguin UK.

Komputer, W. (2007). Tutorial 5 Hari - Desain Grafis Kreatif dengan CorelDraw X4. Andi Publisher. 
Mulyawati, I., \& Pradita, S. M. (2018). Pelatihan Sablon bagi Karang Taruna dalam Menciptakan Peluang Bisnis. Jurnal SOLMA, 7(2), 299-308. https://doi.org/https://doi.org/10.29405/solma.v7i2.1726

Nilawati, Y. J., Budi, A. G. W., \& Mayangsari, M. (2020). Pelatihan Perhitungan Harga Pokok Produksi Usaha Laundry Di Bekasi Jawa Barat. Jurnal Berdaya Mandiri, 2(2), 357-365. https://doi.org/10.31316/jbm.v2i2.693

Rina Fariana, Fauziyah, Teguh Purwanto, \& Bayu Adi. (2020). Pelatihan Pembukuan Sederhana Untuk Meningkatkan Kinerja Keuangan Pelaku Usaha Di Desa Kebontunggul Kecamatan Gondang Kabupaten Mojokerto. Ekobis Abdimas: Jurnal Pengabdian Masyarakat, 1(1), 37-44. https://doi.org/10.36456/ekobisabdimas.1.1.37-44.2339

Saifudin, I., \& Nurhalimah, N. (2019). Screen Printing the Glassware as Souvenir to Increase Selling Value and Income on Handicraft Group in Karangrejo, Jember, East Java. Kontribusia (Research Dissemination for Community Development), 2(1), 24. https://doi.org/10.30587/kontribusia.v2i1.778

Suhendri, H. (2015). Pelatihan dan Pendampingan Usaha Mikro Dhi Sablon \& Printing Dan The Joker's Sablon \& Offset di Malang. Jurnal Dedikasi, 12. https://ejournal.umm.ac.id/index.php/dedikasi/article/view/2474

Yahya, F., Fitriyanto, S., Hermansyah, Syarifuddin, \& Musahrain. (2020). Pelatihan Desain Grafis Untuk Kelompok Pemuda Kreatif Desa Gontar Kecamatan Alas Barat Kabupaten Sumbawa. In Jurnal Pendidikan dan Pengabdian Masyarakat (Vol. 3, Issue 2). https://jurnalfkip.unram.ac.id/index.php/JPPM/article/view/1858 